\title{
Empirical Study on Personal Financial Literacy of University Students for Develop the Financial Education
}

\section{Sirli Mändmaa}

Tallinn University of Technology (TalTech), Estonia

E-mail: sirli.mandmaa@teltech.ee

\section{Estonia}

Abstract

Earlier surveys showed students inadequate knowledge of personal finances and pointed out the need to develop financial education. Researchers had stated that female students tend to display a lower level of personal financial literacy than male students as they have lower self-confidence and less interest to learn about Personal Finance. This study used the data gathered from Estonian university students (210 women, 326 men) by survey questionnaire. The study focused on gender differences in financial knowledge and the choices and opinions that may affect financial literacy. Results showed that females who had chosen the math-based academic discipline had a higher level of financial literacy than male students did. Furthermore, 79\% of women had the interest to improve their knowledge in Personal Finance and their self-confidence was slightly higher than male students. The results obtained give the direction for future research and enable it to enhance financial education.

\section{KEYWORDS: financial literacy assessment; financial education; gender differences; university student}

\section{Introduction}

Financial literacy gives individuals the ability to make informed financial choices. 'Just as it was not possible to contribute to and thrive in an industrialized society without basic literacy the ability to read and write so it is not possible to successfully navigate today's world without being financially literate.'(Lusardi 2017, 1).

JumpStart Coalition states: "Financial literacy is the ability to use knowledge and skills to manage financial resources effectively for a lifetime of financial well-being." (Remund 2010, 285).

The financial literacy definition used in an international study to assess the financial literacy of young people, PISA 2012', was following: "Financial literacy is knowledge and understanding of financial concepts and risks, and the skills, motivation, and confidence to apply such knowledge and understanding to make effective decisions across a range of financial contexts, to improve the financial well-being of individuals and society, and to enable participation in economic life." (OECD 2014, 33).

\footnotetext{
1 Programme for International Student Assessment (PISA); PISA 2012 financial literacy assessment, was administrated to approximately 29.000 students in 13 OECD countries and economies (Australia, the Flemish Community of Belgium, the Czech Republic, Estonia, France, Israel, Italy; New Zealand, Poland, the Slovak Republic, Slovenia, Spain and United States) and five partner countries and economies (Columbia, Croatia, Latvia, the Russian Federation and Shanghai-China) (OECD 2014).
}

Around the world, there are many different definitions of financial literacy, but the important component of these all is knowledge, which must be passed on to humans.

Several studies throughout the world have shown gender differences in financial knowledge. Researchers have argued that females tend to display lower level on personal financial literacy than males, among adults (Fonseca et al. 2010; Lusardi \& Mitchell 2006; Monticone 2010; OECD 2012), students (Atkinson et al. 2006; Chen and Volpe 1998; Chen and Volpe 2002; Goldsmith et al. 1997; E. Goldsmith and R.E. Goldsmith 2006; Mändmaa 2019a; Mändmaa 2019b), and adolescents (Lusardi, Mitchell and Curto 2010). E. Goldsmith and R.E. Goldsmith $(1997 ; 2006)$ suggest that females have a lower level in financial literacy than males as their general interest in investment and personal finance is usually lower, and they are less confident in their ability to perform financial analysis. Following the same line of reasoning, Chen and Volpe (2002) found that women generally have not only less knowledge about personal finance, but also have less enthusiasm for, lower confidence in, and less willingness to learn about personal finance topics than men do. As Personal Finance is mostly a number-oriented subject it is not attractive to women, as women prefer courses with less mathematics and other number-oriented science. Chen and Volpe (2002) concluded that enthusiasm and confidence may be the contributing factors that explain 


\section{(C) Center for Promoting Education and Research (CPER) USA}

https://ijbassnet.com/

why men are more financially knowledgeable than women.

To draw conclusions and make suggestions for the promotion of financial education, it is important to assess the existing knowledge. Understanding how and why male and female students have different levels of financial literacy allows better improvement in financial education.

"Financial education is the process by which financial consumers/investors improve their understanding of financial products and concepts and, through information, instruction and/or objective advice, develop the skills and confidence to become aware of (financial) risks and opportunities, to make informed choices, to know where to go for help, and to take other effective actions to improve their financial well-being and protection." (OECD 2006, 118).

The objects of the current survey are students studying in higher education institutions in Estonia. University students are the future decision-makers and due to better jobs higher positions, bigger salaries - the most promising segment of using financial services. The lack of their financial knowledge may lead to catastrophically consequences not only on a personal level but affect the well-being of society as well.

The goal of this study is to assess the financial knowledge of female and male students' and the factors influencing their financial literacy level, in purpose to provide starting points for improving financial education. Since knowledge is closely tied with the individual's education, the study observes students' sources of financial education too.

\subsection{Results and Conclusions of Previous Studies}

PISA 2012 was the first large-scale international study to assess the financial literacy of young people. There were no remarkable differences in girls' and boys' financial literacy in any participated country but if look at the results of boys and girls in math and reading tests, then out of the students with similar scores, boys had a higher level of financial literacy in 12 of 18 countries, including in Estonia. Studies conducted among adults in some of the countries and economies that were participating in the 2012 PISA financial literacy assessment as well, reported that men perform better than women on surveys measuring financial knowledge. As argued, to some extent gender differences in adulthood are related to the different socio-economic characteristics of men and women. OECD 2014)
WWW.cpernet.org

Various studies (Chen and Volpe 1998; Mandell 2008; Mändmaa 2019a; Mändmaa 2019b; Pires and Quelhas 2015) examined students' financial knowledge and revealed that students with an economic academic discipline or individuals attending programs in business sciences tend to exhibit a higher level in financial literacy. Lewis Mandell, who was surveying the Financial Literacy of Young American Adults, released his opinion: "Regardless of major, college students learn how to do research and solve problems. In a rapidly changing financial system, these two skills are more important to financial decision-making than understanding financial products, rules, and regulations. Knowing how to approach a problem and how to research it is key to making the best personal financial decisions." (Mandell 2008, 29) According to the results, students who study science and engineering have the highest financial literacy scores, and those who study business or economics come next. (Mandell 2008)

The research among Portuguese students revealed that the existence of a prior experience, as credit clients or the existence of saving habits increases the financial literacy of individuals (Pires and Quelhas 2015). The survey among Estonian students showed that financial literacy and using financial services have a statistically significant connection (Mändmaa 2019b).

Financial literacy can have important implications for financial behavior. Previous research has found that people with low financial literacy are more likely to have problems with debt (Lusardi and Tufano 2009), and less likely to participate in the stock market (van Rooij, Lusardi, and Alessie 2007). Financial education improves credit scores, and dramatically reduces the probability of declaring bankruptcy, as well as increases significantly investment income and retirement savings (Cole, Paulson and Shastry 2012).

Financial literacy is an important component of sound financial decision-making. In a 2009 survey on credit card use among undergraduate students, 84 percent of students said they were interested in pursuing some areas of education to increase financial literacy, and 64 percent of them would have liked to receive information in high school and 40 percent as a college freshman (Sallie Mae 2009). In a survey that was organized among Estonian university students, to the question about "Do you want to get more information about financial services and monetary affairs planning?" 65 percent answered "yes". Students with low financial literacy were more 
interested, as 55 percent of the "yes" answers came from them. (Mändmaa 2019a).

\section{Methodology and Data}

This study uses a standardized survey method to assess participants' financial literacy. The questionnaire was designed to cover major aspects of personal finance and included knowledge on general personal finance, saving, borrowing, investment, and insurance. The survey participants were asked to answer multiple-choice questions. This study includes 10 questions on demographic data, 23 questions to measure financial literacy, and five questions about students' opinions and choices. The validity and clarity of the survey questions were evaluated by experts knowledgeable in personal finance.

The responses from each participant were used to calculate the median and mean percentage of correct scores, to measure the financial literacy levels and to analyze the results. Consistent with the existing literature (Chen and Volpe 1998; Mändmaa 2019a, 2019b), the mean percentage of correct scores were grouped into three categories. The first category represents a relatively high level (High-more than 80\%) of knowledge, the second a medium (Medium 60\% to $79 \%$ ), and the third represents a relatively low level (Low-below 60\%) of knowledge. The median percentage was used in the analysis to divide participants into two groups. Students with scores higher than the median were classified as students with relatively higher (More) knowledge and students with scores equal or below the median were classified as those with relatively lower (Less) knowledge.

Previous research advised that levels of financial literacy vary among subgroups of students (Chen and Volpe 1998, 2002; Mändmaa 2019a, 2019b). To provide evidence of the differences the Analysis of variance (ANOVA) was used.

Participants' choices to use financial services, opinions about their finance, and evaluation of sources of personal financial education, were explored. Crosstabulation and Chi-Square tests were used to determine differences between female and male participants. The differences were further analyzed by using ANOVA.

Based on previous research results, the students studying in math-based disciplines mostly engineering, were chosen as subjects of this study. To increase participation the poll was conducted during the lectures on the paper form. There were 536 students from Tallinn University of Technology (TalTech, one of the leading technological universities in the Baltic Sea region), participated in the poll. Students who studied civil engineering $(82.5 \%)$ were a large part of the participants. In terms of gender, female participants accounted for about $39 \%$ of the sample, and male participants for $61 \%$.

The characteristics of the sample by gender are presented in Table 1. There were five noticeable differences. First, most of the participants were Estonians $(83 \%)$, but there was a difference between female and male participants, as there were six percent more NonEstonians among female participants. Second, the higher proportion of male participants was at a higher level of education than female participants. About $70 \%$ of male participants were studying in Master or Integrated studies, while only about $61 \%$ of female participants were at the same level of education. Third, male participants were older than female participants. About 39\% of male participants were older than 23 years, while only $32 \%$ of the female students were in these age groups. Fourth, the differences in participant's households: About 39\% of male students stated that they live with parents or grandparents, which was their most preferred choice and exceeded the female students' same choice by 8 percent. About $26 \%$ of female participants lived together with the life partner, while only $14 \%$ of male participants had made the same choice. Fifth, there were differences in the background. Noteworthy was the existence of participant's mothers' higher education, which was significantly higher for both female and male students, than the existence of fathers' higher education (differences accordingly 15\% and $13 \%)$. 


\section{Table 1 Characteristics of the Sample}

\begin{tabular}{|c|c|c|c|c|c|c|}
\hline \multirow[t]{2}{*}{ Characteristics } & \multicolumn{2}{|c|}{ Female participants } & \multicolumn{2}{|c|}{ Male participants } & \multicolumn{2}{|c|}{ Entire sample participants } \\
\hline & Frequency & $\%$ & Frequency & $\%$ & Frequency & $\%$ \\
\hline Total amount of observations & 210 & 100 & 326 & 100 & 536 & 100 \\
\hline \multicolumn{7}{|l|}{ A. Education } \\
\hline \multicolumn{7}{|l|}{ 1. Academic discipline } \\
\hline a) Civil Engineering & 178 & 84.7 & 269 & 82.5 & 447 & 82.5 \\
\hline b) Other & 32 & 15.3 & 57 & 17.5 & 89 & 17.5 \\
\hline Inc. Info technology & 8 & 3.8 & 32 & 9.8 & 40 & 7.4 \\
\hline Mathematics & 9 & 4.3 & 7 & 2.1 & 16 & 3.0 \\
\hline Economic & 10 & 4.8 & 5 & 1.5 & 15 & 2.8 \\
\hline \multicolumn{7}{|l|}{ 2. Level of education } \\
\hline a) Bachelor studies & 81 & 38.3 & 96 & 29.5 & 177 & 33.0 \\
\hline b) Master studies & 36 & 17.2 & 59 & 18.1 & 95 & 17.8 \\
\hline c) Integrated Bachelor's and Master's Study & 92 & 44.0 & 168 & 51.5 & 260 & 48.5 \\
\hline d) Unanswered & 1 & 0.5 & 3 & 0.9 & 4 & 0.7 \\
\hline \multicolumn{7}{|l|}{ B. Experience } \\
\hline \multicolumn{7}{|l|}{ 1. Age groups } \\
\hline a) $18-22$ & 142 & 67,6 & 198 & 60.7 & 340 & 63.4 \\
\hline b) 23-29 & 55 & 26,2 & 102 & 31.3 & 157 & 29.3 \\
\hline c) 30 and up & 13 & 6,2 & 26 & 8.0 & 39 & 7.3 \\
\hline \multicolumn{7}{|l|}{ 2. The work experience } \\
\hline a) None & 67 & 31.9 & 104 & 31.9 & 171 & 31.9 \\
\hline b) Less than 2 years & 81 & 38.6 & 126 & 38.7 & 207 & 38.6 \\
\hline c) 2 to 5 years & 40 & 19.0 & 43 & 13.2 & 83 & 15.5 \\
\hline d) More than 5 years & 16 & 7.6 & 50 & 15.3 & 66 & 12.3 \\
\hline e) Unanswered & 6 & 2.9 & 3 & 0.9 & 9 & 1.7 \\
\hline \multicolumn{7}{|l|}{ C. Demographic characteristics } \\
\hline \multicolumn{7}{|l|}{ 1. Nationality } \\
\hline a) Non-Estonian & 43 & 20.5 & 48 & 14.7 & 91 & 17.0 \\
\hline b) Estonian & 167 & 79.5 & 278 & 85.3 & 445 & 83.0 \\
\hline \multicolumn{7}{|l|}{ 2. Gender } \\
\hline a) Male & 0 & 0 & 326 & 100 & 326 & 60.8 \\
\hline b) Female & 210 & 100 & 0 & 0 & 210 & 39.2 \\
\hline \multicolumn{7}{|l|}{ 3. Household size } \\
\hline a) Live alone & 54 & 25.7 & 102 & 31.2 & 156 & 29.1 \\
\hline b) Live with husband/ wife & 55 & 26.2 & 45 & 13.8 & 100 & 18.7 \\
\hline c) Live with husband/ wife and children & 13 & 6.2 & 27 & 8.3 & 40 & 7.5 \\
\hline d) Live with parents/grandparents & 64 & 30.5 & 126 & 38.7 & 190 & 35.4 \\
\hline e) Other & 24 & 11.4 & 26 & 8.0 & 50 & 9.3 \\
\hline \multicolumn{7}{|l|}{ D. Income } \\
\hline \multicolumn{7}{|l|}{ 1. Personal monthly net income } \\
\hline a) Do not want to answer & 36 & 17.1 & 61 & 18.7 & 97 & 18.1 \\
\hline b) Under 300 EURO & 90 & 42.9 & 129 & 39.6 & 219 & 40.9 \\
\hline c) 301- 750 EURO & 52 & 24.8 & 70 & 21.5 & 122 & 22.8 \\
\hline d) 751 EURO and over & 32 & 15.2 & 66 & 20.2 & 98 & 18.2 \\
\hline \multicolumn{7}{|l|}{ E. Background } \\
\hline \multicolumn{7}{|l|}{$\begin{array}{l}\text { 1. Educational level of parents - existence } \\
\text { of higher education }\end{array}$} \\
\hline a) Mother & 120 & 57.1 & 207 & 63.5 & 327 & 61.0 \\
\hline b) Father & 88 & 41.9 & 166 & 50.9 & 254 & 47.4 \\
\hline c) Stepparent & 11 & 5.2 & 12 & 3.7 & 23 & 4.3 \\
\hline d) Grandparent & 44 & 21.0 & 69 & 21.2 & 113 & 21.1 \\
\hline 2. Number of books in childhood home & & & & & & \\
\hline a) Under 100 & 54 & 25.7 & 76 & 23.3 & 130 & 24.3 \\
\hline b) $101-500$ & 112 & 53.3 & 176 & 54.0 & 288 & 53.7 \\
\hline c) More than 500 & 39 & 18.6 & 68 & 20.9 & 107 & 20.0 \\
\hline d) Unanswered & 5 & 2.4 & 6 & 1.8 & 11 & 2,0 \\
\hline
\end{tabular}

\section{Results}

The survey was conducted to evaluate the level of financial literacy and analyze the factors that influence female and male students' financial knowledge. The Social Sciences (SPSS). questionnaire was filled in by 536 university students (210 female and 326 male). The collected data were analyzed using the software Statistical Package for the 


\section{(c) Center for Promoting Education and Research (CPER) USA}

\subsection{Differences in Personal Financial Literacy}

Table 2 summarizes the survey responses and shows differences in financial literacy by gender. The results were presented by topic, followed by question numbers and a brief description. The first section was on general personal finance knowledge (9 questions) and the second on saving, borrowing, insurance, and investments (14 questions).

In Section I, if compared male and female showed that participants' financial literacy was at the students' knowledge the average scores were almost Medium level.

\section{Table 2 Mean percentages of correct responses by gender and result of ANOVA}

\begin{tabular}{|c|c|c|c|c|c|c|c|c|c|c|}
\hline & \multicolumn{9}{|c|}{$\begin{array}{l}\text { Level of Personal Financial Literacy } \\
\end{array}$} & \multirow{3}{*}{$\begin{array}{c}\text { Total } \\
\%\end{array}$} \\
\hline & \multicolumn{3}{|c|}{ Low Below 60\% } & \multicolumn{3}{|c|}{ Medium 60-79\% } & \multicolumn{3}{|c|}{ High Over 80\% } & \\
\hline & M & $\mathbf{F}$ & F test & M & $\mathbf{F}$ & F test & M & $\mathbf{F}$ & F test & \\
\hline \multicolumn{11}{|c|}{ I General Personal finance knowledge } \\
\hline 1. Personal financial literacy & & & & 73.9 & 70.0 & 0.983 & & & & 72.4 \\
\hline 2. Asset liquidity & 41.1 & 48.6 & 2.895 & & & & & & & 44.0 \\
\hline 3. Definition of inflation & & & & 71.8 & 77.1 & 1.904 & & & & 73.9 \\
\hline 4. Time-value of money & & & & & & & 79.4 & 83.3 & 1.250 & 81.0 \\
\hline 5. Interest paid on a loan & & & & & & & 95.7 & 96.2 & 0.076 & 95.9 \\
\hline 6. Cost of apartment leasing & & & & 68.1 & 69.0 & 0.053 & & & & 68.5 \\
\hline $\begin{array}{l}\text { 7. Legal requirement for apartment } \\
\text { lease }\end{array}$ & & & & 66.9 & 70.0 & 0.574 & & & & 68.1 \\
\hline $\begin{array}{l}\text { 8. Change in the purchasing power of } \\
\text { money }\end{array}$ & 59.5 & 50.9 & $3.811 *$ & & & & & & & 56.2 \\
\hline 9. Discount valuation & & & & & & & 97.8 & 96.7 & 0.705 & 97.4 \\
\hline $\begin{array}{l}\text { Mean correct responses for the I } \\
\text { section }\end{array}$ & & & & 72.7 & 73.5 & 0.332 & & & & 73.0 \\
\hline \multicolumn{11}{|c|}{ II Saving, borrowing, insurance and investments } \\
\hline 10. Appropriate saving place & & & & 76.1 & 76.7 & 0,025 & & & & 76.3 \\
\hline $\begin{array}{l}\text { 11. Calculation of interest plus } \\
\text { principle }\end{array}$ & & & & & & & 89.3 & 90.5 & 0.203 & 89.7 \\
\hline 12. Compound interest & & & & 65.3 & 66.7 & 0.100 & & & & 65.9 \\
\hline 13. Purchasing power assessment & & & & & & & 83.1 & 88.6 & 3.016 & 85.3 \\
\hline 14. Monthly payments of mortgage & & & & 68.1 & 70.5 & 0.337 & & & & 69.0 \\
\hline 15. Interest of loan & 53.4 & 56.7 & 0.557 & & & & & & & 54.7 \\
\hline 16. Loan co-sing consequences & & & & 59.5 & 66.2 & 2.425 & & & & 62.1 \\
\hline 17. The interest rate evaluation & & & & & & & 89.0 & 91.0 & 0.551 & 89.7 \\
\hline $\begin{array}{l}\text { 18. Understanding the content of } \\
\text { insurance }\end{array}$ & 35.6 & 38.6 & 0.489 & & & & & & & 36.7 \\
\hline 19. Homeowners' insurance & 33.1 & 43.3 & $5.737 *$ & & & & & & & 37.1 \\
\hline $\begin{array}{l}\text { 20. Revenue of different Interest } \\
\text { calculation }\end{array}$ & 46.9 & 49.5 & 0.343 & & & & & & & 47.9 \\
\hline 21. Diversification & & & & 78.5 & 80.9 & 0.459 & & & & 79.5 \\
\hline 22. Risk and return & & & & & & & 81.9 & 84.8 & 0.739 & 83.0 \\
\hline $\begin{array}{l}\text { 23. Interest rates changes and } \\
\text { treasury bond price }\end{array}$ & 15.3 & 22.9 & $4.860^{*}$ & & & & & & & 18.3 \\
\hline $\begin{array}{l}\text { Mean correct responses for the II } \\
\text { section }\end{array}$ & & & & 62.5 & 66.2 & $5.243^{*}$ & & & & 63.9 \\
\hline $\begin{array}{l}\text { Mean correct responses for the entire } \\
\text { survey }\end{array}$ & & & & 66.5 & 69.1 & $3.683^{*}$ & & & & 67.5 \\
\hline \multicolumn{4}{|c|}{ Median correct responses for the entire survey } & 69.6 & 73.9 & & & & & 69.6 \\
\hline
\end{tabular}

Notes: "M" average score of male participants; "F" average score of female participants; F test marks F-statistics value; * significant at the 0.05 level. 


\section{Sample}

\subsection{Analysis of Results by Subgroups of the}

The ANOVA results in the previous section showed the gender differences in financial literacy, but the effects of other determining factors were not controlled. In this section, the relationship between personal financial literacy and the characteristics of the sample were examined (Table.3). The ANOVA had been used to detect if participants from various subgroups have differences in levels of financial knowledge.

Participants' educational background had a significant impact on their financial knowledge. The results for the entire survey clearly showed that students from the Civil Engineering department were more knowledgeable than students from other educational disciplines. On average, the students who studied engineering answered $71 \%$ (Female participants $73 \%$ and Male participants $71 \%$ ) of the survey questions correctly, while on other disciplines the scores varied between $41 \%$ to $56 \%$. The findings also suggested that participants from a different level of education had different levels of financial knowledge, and the students of Master studies knew more than students at Integrated studies or Bachelor studies. The testing results of ANOVA indicated that the differences in the Education area were statistically significant at the 0.01 level.

The participants from different age groups had different levels of financial knowledge. The group of youngest students (18-22) got the lowest score (67\%) and the group of oldest students (30 and up) reached the highest $(73 \%)$ score. These results were statistically significant at the 0.05 level and were as expected, as knowledge grows over time. The work experience, which grows over time and broadens people's perceptions, was also a statistically significant factor (at the 0.01 level) that affected financial literacy. In the subgroup Experience, the results did not have remarkable gender differences.

Findings showed students' different demographic characteristics influenced their financial knowledge. The nationality influenced the level of financial literacy and the difference between Estonians and non-Estonians correct answers scores was 4\%. The growth of the personal household size had a positive impact on financial literacy. The difference in students' financial literacy in a situation where the student lived alone (67\%) or lived together with partners and children (70\%) was 3\%. The different scores in this subgroup were statistically significant at the 0.05 level.

The differences in financial knowledge in the subgroup, Personal monthly net income, were statistically significant at the 0.01 level and the financial literacy level rose together with income. Students' who revealed their monthly income less than 300 EURO, had the average score of correct answers $67 \%$, and students who earned over 750 EURO per month, the score of correct answers was $72 \%$. In the subgroup Income, the differences in results of female and male participants were similar.

Based on F-statistic values there were no significant differences in a subgroup named Background (Level of education of the parents and Number of books in childhood home).

Table 3 Characteristics of the Sample with percentage of correct answers by gender, and results of ANOVA

\begin{tabular}{|c|c|c|c|}
\hline & Female participants \% & Male participants \% & Entire sample \% \\
\hline \multicolumn{4}{|l|}{ A. Education } \\
\hline \multicolumn{4}{|l|}{ 1. Academic discipline } \\
\hline a) Civil engineering & 72.54 & 70.78 & 71.48 \\
\hline b) Info technology & 55.98 & 47.83 & 49.45 \\
\hline c) Mathematics & 41.06 & 41.61 & 41.30 \\
\hline d) Economic & 49.56 & 41.74 & 46.95 \\
\hline e) Other departments & 55.65 & 46.82 & 49.27 \\
\hline F Statistic & $(26.518)^{* * *}$ & $46.678^{* *}$ & $(71.183)^{* *}$ \\
\hline \multicolumn{4}{|l|}{ 2. Level of education } \\
\hline a) Bachelor studies & 69.73 & 61.41 & 65.22 \\
\hline b) Master studies & 75.97 & 73.32 & 74.32 \\
\hline c) Integrated Bachelor's and Master's Study & 65.88 & 67.34 & 66.82 \\
\hline d) Unanswered & 60.87 & 47.83 & 47.83 \\
\hline F Statistic & $(4.490)^{* *}$ & $(9.650)^{* *}$ & $(10,066)^{* *}$ \\
\hline \multicolumn{4}{|l|}{ B. Experience } \\
\hline \multicolumn{4}{|l|}{ 1. Age groups } \\
\hline a) $18-22$ & 68.83 & 65.22 & 66.73 \\
\hline b) $23-29$ & 68.54 & 67.39 & 67.79 \\
\hline c) 30 and up & 73.91 & 72.74 & 73.13 \\
\hline F Statistic & $(0,764)$ & $(3.013)^{*}$ & $(3.183)^{*}$ \\
\hline 2. The work experience & & & \\
\hline
\end{tabular}




\section{(c) Center for Promoting Education and Research (CPER) USA}

\begin{tabular}{|c|c|c|c|}
\hline a) None & 66.45 & 64.51 & 65.27 \\
\hline b) Less than 2 years & 69.03 & 65.08 & 66.24 \\
\hline c) 2 to 5 years & 72.17 & 69.06 & 70.56 \\
\hline d) More than 5 years & 73.37 & 72.00 & 72.33 \\
\hline e) Unanswered & 66.67 & 66.67 & 66.67 \\
\hline F Statistic & $(1.380)$ & $(2.632)^{*}$ & $(3.693)^{* *}$ \\
\hline \multicolumn{4}{|l|}{ C. Demographic characteristics } \\
\hline \multicolumn{4}{|l|}{ 1. Nationality } \\
\hline a) Estonian & 69.28 & 67.66 & 68.26 \\
\hline b) Non-Estonian & 68.25 & 59.78 & 63.78 \\
\hline F Statistic & $(0,168)$ & $(10.965)^{* *}$ & $(6.659)^{*}$ \\
\hline \multicolumn{4}{|l|}{ 2. Gender } \\
\hline a) Male & - & - & 66.50 \\
\hline b) Female & - & - & 69.07 \\
\hline F Statistic & - & - & $(3.683)^{*}$ \\
\hline \multicolumn{4}{|l|}{ 3. Household size } \\
\hline a) Live alone & 67.79 & 67.01 & 67.28 \\
\hline b) Live with husband/ wife & 71.70 & 67.34 & 69.74 \\
\hline c) Live with husband/ wife and children & 70.23 & 69.89 & 70.00 \\
\hline d) Live with parents/grandparents & 65.42 & 64.77 & 64.99 \\
\hline e) Other & 75.00 & 67.89 & 71.30 \\
\hline F Statistic & $(2.622)^{*}$ & $(0.833)$ & $(2.953)^{*}$ \\
\hline \multicolumn{4}{|l|}{ D. Income } \\
\hline \multicolumn{4}{|l|}{ 1. Personal monthly net income } \\
\hline a) Do not want to answer & 65.82 & 59.80 & 62.03 \\
\hline b) Under 300 EURO & 68.69 & 65.59 & 66.86 \\
\hline c) 301- 750 EURO & 69.81 & 68.57 & 69.10 \\
\hline d) 750 EURO and over & 72.55 & 72.27 & 72.36 \\
\hline F Statistic & $(1.264)$ & $7.939 * *$ & $(8.465)^{* * *}$ \\
\hline \multicolumn{4}{|l|}{ E. Background } \\
\hline \multicolumn{4}{|c|}{ 1. Level of education of the parents. Higher education exists } \\
\hline a) Mother & 69.31 & 67.73 & 68.31 \\
\hline b) Father & 68.38 & 66.58 & 67,20 \\
\hline c) Stepparent & 70.75 & 71.74 & 71.27 \\
\hline d) Grandparent & 68.67 & 66.29 & 67.22 \\
\hline F Statistic & $(0.040)$ & $(0,016)$ & $(0,051)$ \\
\hline \multicolumn{4}{|l|}{ 2. Number of books in childhood home } \\
\hline a) Under 100 & 70.21 & 66.30 & 67.93 \\
\hline b) $101-500$ & 68.94 & 65.46 & 66.82 \\
\hline c) More than 500 & 68.34 & 69.88 & 69.32 \\
\hline d) Unanswered & 65.22 & 60.87 & 65.84 \\
\hline F Statistic & $(0,257)$ & $(1.632)$ & $(1.002)$ \\
\hline
\end{tabular}

Notes: *significant at the 0.05 level; **significant at the 0.01 level or greater.

3.3 Analysis of Results by Participants' Choices financial knowledge and vice versa the financial services Analysis of variance had used to detect if users had higher financial literacy levels. (Table 4, participants with different financial choices had different levels of financial knowledge. Based on earlier studies (Pires and Quelhas, 2015; Mändmaa 2019b) the use of financial services has an impact on students' financial literacy.

Current study results showed that financial services having a statistically significant effect were: Current Account, Debit Card, Housing loan (only on male participants'), Insurance, Investment Services, Pension fund shares, and Credit Card. To describe the users of statistically significant financial services the Crosstabulation and Chi-square tests had run. The results are exposed in Table 4.

Students with higher levels of financial literacy used financial services more than students with lower columns 8 and 9). The argument had confirmed by choices made by students studying in Civil Engineering department (Table 4, columns 2 and 3), who were significantly more active users of financial services than students from other study fields (Table 3, Financial literacy scores in Civil Engineering $71-73 \%$ and Others $41-56 \%$ ).

Differences in students' choices on using Debit Card were statistically significant and confirmed earlier argument, as Non-Estonian students share among debit card users was $11 \%$ smaller (Table 4, 81\% of Estonians and $70 \%$ of Non-Estonians) and their financial literacy score was 4\% lower (Table 3, Estonians 68\% and NonEstonians 64\%).

Based on Chi-square tests there were no significant differences between female and male students' 
choices (Table 4), and as the tests, statistical significance was over 0.05 these generalizations are not appropriate.

Table 4 Description about users of currently available financial services

\begin{tabular}{|c|c|c|c|c|c|c|c|c|}
\hline A. Using the Current Account & CED & Other & $\begin{array}{l}\text { Estoni } \\
\text { an }\end{array}$ & Non-Estonian & Male & Female & FL less & FL more \\
\hline 1 & 2 & 3 & 4 & 5 & 6 & 7 & 8 & 9 \\
\hline Count & 392 & 60 & 379 & 73 & 272 & 180 & 169 & 283 \\
\hline$\%$ of column & 87.7 & 67.4 & 85.2 & 80.2 & 83.4 & 85.7 & 72.8 & 93.1 \\
\hline Count & 55 & 29 & 66 & 18 & 54 & 30 & 63 & 21 \\
\hline$\%$ of column & 12.3 & 32.6 & 14.8 & 19.8 & 16.6 & 14.3 & 27.2 & 6.9 \\
\hline Count & 447 & 89 & 445 & 91 & 326 & 210 & 232 & 304 \\
\hline$\%$ of Total & 83.4 & 16.6 & 83.0 & 17.0 & 60.8 & 39.2 & 43.3 & 56.7 \\
\hline & \multicolumn{2}{|c|}{ Chi-Square $=23.098^{* *}$} & \multicolumn{2}{|c|}{ Chi-Square $=1.400$} & \multicolumn{2}{|c|}{ Chi-Square $=0.502$} & \multicolumn{2}{|c|}{ Chi-Square $=40.817 * *$} \\
\hline B. Using the Debit Card & 2 & 3 & 4 & 5 & 6 & 7 & 8 & 9 \\
\hline Count & 368 & 57 & 361 & 64 & 262 & 163 & 161 & 26 \\
\hline$\%$ of column & 82.3 & 64.0 & 81.1 & 70.3 & 80.4 & 77.6 & 69.4 & 86.8 \\
\hline Count & 79 & 32 & 84 & 27 & 64 & 47 & 71 & 40 \\
\hline$\%$ of column & 17.7 & 36.0 & 18.9 & 29.7 & 19.6 & 22.4 & 30.6 & 13.2 \\
\hline Count & 447 & 89 & 445 & 91 & 326 & 210 & 232 & 304 \\
\hline \multirow[t]{2}{*}{$\%$ of Total } & 83.4 & 16.6 & 83.0 & 17.0 & 60.8 & 39.2 & 43.3 & 56.7 \\
\hline & \multicolumn{2}{|c|}{ Chi-Square $=15.107^{\star *}$} & \multicolumn{2}{|c|}{ Chi-Square $=5.361 *$} & \multicolumn{2}{|c|}{ Chi-Square $=0.588$} & \multicolumn{2}{|c|}{ Chi-Square $=24.388 * *$} \\
\hline C. Using the Credit Card & 2 & 3 & 4 & 5 & 6 & 7 & 8 & 9 \\
\hline Count & 99 & 12 & 97 & 14 & 69 & 42 & 37 & 74 \\
\hline$\%$ of column & 22.1 & 13.6 & 21.8 & 15.4 & 21.2 & 20.0 & 15.9 & 24.3 \\
\hline Count & 301 & 61 & 299 & 63 & 215 & 147 & 155 & 207 \\
\hline$\%$ of column & 67.3 & 69.3 & 67.2 & 69.2 & 66.0 & 70.0 & 66.8 & 68.1 \\
\hline Yes, but not my own Count & 38 & 9 & 38 & 9 & 34 & 13 & 27 & 20 \\
\hline$\%$ of column & 8.5 & 10.2 & 8.5 & 9.9 & 10.4 & 6.2 & 11.6 & 6.6 \\
\hline Unanswered Count & 9 & 7 & 11 & 5 & 8 & 8 & 13 & 3 \\
\hline$\%$ of column & 2.0 & 6.8 & 2.5 & 5.5 & 2.5 & 3.8 & 5.6 & 1.0 \\
\hline Count & 447 & 89 & 445 & 91 & 326 & 210 & 232 & 304 \\
\hline \multirow[t]{2}{*}{$\%$ of Total } & 83.6 & 16.4 & 83.0 & 17.0 & 60.8 & 39.2 & 43.3 & 56.7 \\
\hline & \multicolumn{2}{|c|}{ Chi-Square $=8.913^{\star}$} & \multicolumn{2}{|c|}{ Chi-Square $=4.016$} & \multicolumn{2}{|c|}{ Chi-Square $=3.797$} & \multicolumn{2}{|c|}{ Chi-Square $=17.744^{* *}$} \\
\hline D. Using Housing loan & 2 & 3 & 4 & 5 & 6 & 7 & 8 & 9 \\
\hline Count & 31 & 1 & 30 & 2 & 21 & 11 & 11 & 21 \\
\hline$\%$ of column & 6.9 & 1.1 & 6.7 & 2.2 & 6.4 & 5.2 & 4.7 & 6.9 \\
\hline Count & 416 & 88 & 415 & 89 & 305 & 199 & 221 & 283 \\
\hline$\%$ of column & 93.1 & 98.9 & 93.3 & 97.8 & 93.6 & 94.8 & 95.3 & 93.1 \\
\hline Count & 447 & 89 & 445 & 91 & 326 & 210 & 232 & 304 \\
\hline$\%$ of Total & 83.4 & 16.9 & 83.0 & 17.0 & 60.8 & 39.2 & 43.3 & 56.7 \\
\hline & Chi-Square & $=4.465^{*}$ & Chi-Squ & $\mathrm{re}=2.779$ & Chi-Squa & $=0.330$ & Chi-Square $=$ & .100 \\
\hline E. Using Insurance Services & 2 & 3 & 4 & 5 & 6 & 7 & 8 & 9 \\
\hline Count & 143 & 15 & 138 & 20 & 101 & 57 & 52 & 106 \\
\hline$\%$ of column & 32.0 & 16.9 & 31.0 & 22.0 & 31.0 & 27.1 & 22.4 & 34.9 \\
\hline Count & 304 & 74 & 307 & 71 & 225 & 153 & 180 & 198 \\
\hline$\%$ of column & 68.0 & 83.1 & 69.0 & 78.0 & 69.0 & 72.9 & 77.6 & 65.1 \\
\hline Count & 447 & 89 & 445 & 91 & 326 & 210 & 232 & 304 \\
\hline$\%$ of Total & 83.4 & 16.6 & 83.0 & 17.0 & 60.8 & 39.2 & 43.3 & 56.7 \\
\hline & Chi-Square & $8.181^{\star *}$ & Chi-Squ & $\mathrm{re}=2.966$ & Chi-Squa & $=0.905$ & Chi-Square $=$ & $.818 * *$ \\
\hline F. Using Investment Services & 2 & 3 & 4 & 5 & 6 & 7 & 8 & 9 \\
\hline $\begin{array}{lll}\text { Yes } & \text { Count }\end{array}$ & 40 & 1 & 36 & 5 & 23 & 18 & 6 & 35 \\
\hline$\%$ of column & 8.9 & 1.1 & 8.1 & 5.5 & 7.1 & 8.6 & 2.6 & 11.5 \\
\hline Count & 407 & 88 & 409 & 86 & 303 & 192 & 226 & 269 \\
\hline$\%$ of column & 91.1 & 98.9 & 91.9 & 94.5 & 92.9 & 91.4 & 97.4 & 88.5 \\
\hline Count & 447 & 89 & 445 & 91 & 326 & 210 & 232 & 304 \\
\hline$\%$ of Total & 83.4 & 16.6 & 83.0 & 17.0 & 60.8 & 39.2 & 43.3 & 56.7 \\
\hline & Chi-Square & $6.433^{\star \star}$ & Chi-Squ & $\mathrm{re}=0.720$ & Chi-Squa & $=0.416$ & Chi-Square $=$ & $4.844 * *$ \\
\hline G. Using Pension fund shares & 2 & 3 & 4 & 5 & 6 & 7 & 8 & 9 \\
\hline Count & 138 & 16 & 125 & 29 & 92 & 62 & 50 & 104 \\
\hline$\%$ of column & 30.9 & 18.0 & 28.1 & 31.9 & 28.2 & 29.5 & 21.6 & 34.2 \\
\hline Count & 309 & 73 & 320 & 62 & 234 & 148 & 182 & 200 \\
\hline$\%$ of column & 69.1 & 82.0 & 71.9 & 68.1 & 71.8 & 70.5 & 78.4 & 65.8 \\
\hline Count & 447 & 89 & 445 & 91 & 326 & 210 & 232 & 304 \\
\hline$\%$ of Total & 83.4 & 16.6 & 83.0 & 17.0 & 60.8 & 39.2 & 43.3 & 56.7 \\
\hline & Chi-Square & $6.027^{* *}$ & Chi-Squ & $\mathrm{re}=0.527$ & Chi-Squa & $=0.106$ & Chi-Square= & $0.297 * *$ \\
\hline
\end{tabular}




\section{(C) Center for Promoting Education and Research (CPER) USA}

WWW.cpernet.org

\begin{abstract}
3.4. Relationships between Interest, Selfassessment, Confidence and Financial Literacy

Three different samples and the answers for two questions had used to analyze this topic. The first question examined participants' interest in improving their financial literacy (results in Figure 1) and the second asked them to evaluate their financial knowledge (results in Table 5).
\end{abstract}

Figure 1 describes participants' interest in financial topics through the differences by gender and financial literacy (FL) levels. The results showed that male students had more interested $(84 \%$ of males and $79 \%$ of females), but female students had a higher level of financial literacy (females' 69\% and males 66\%). About $82 \%$ of all students participated in the poll admitted their interest to improve financial literacy level and only $8 \%$ of participants found that there no need for improvement (F Statistic $=4.724$ significant at 0,009 level).

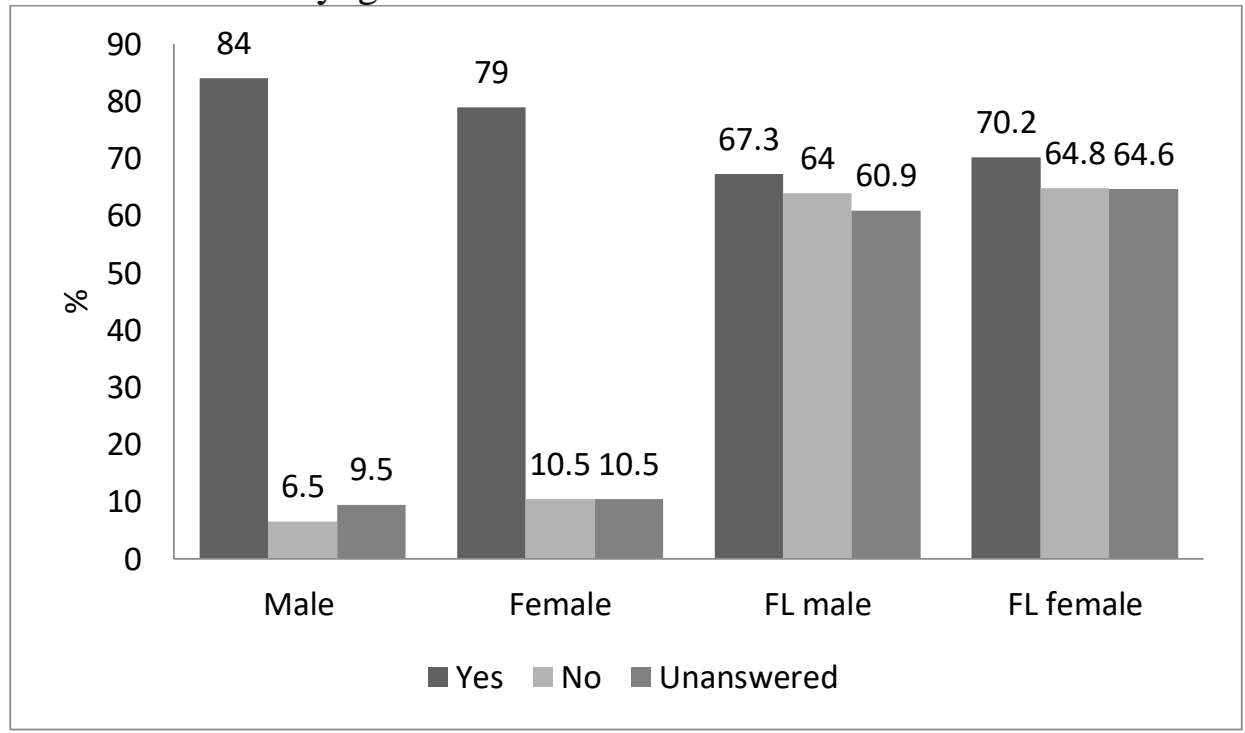

Figure 1 Students' interest about financial topics by gender and financial literacy

$46 \%$ of females and $39 \%$ of male students rated their financial literacy level to "High" and only $8 \%$ of women and $9 \%$ of men rated their level to "Low". The results about the evaluation of participants' financial literacy showed that $24 \%$ of females' and $17 \%$ of males had financial knowledge at a high level, and $24 \%$ of women and $27 \%$ of men had scored at a low level (Table $5)$. The level of own financial literacy had assessed rightly by 203 students, which accounted for $38 \%$ of the total number of respondents in the full sample (Table 5 A) and similar proportions were in samples "Female" (39\%, Table 5 B) and "Male" (37\%, Table 5 C). These results could be concluded that students had overrated their knowledge, as in full sample the $42 \%$ of students evaluated their knowledge to the high level, but only $20 \%$ of those in the survey exceeded the high-level border (right answers $80 \%$ and over). The students who assessed their financial knowledge to the high level (225 incl. 97 female students, i.e. $46 \%$ of females and 128 male students, i.e. $39 \%$ of males) could be counted as self-confident, as well these students (55 incl. 17 female students, and 38 male students) whose financial literacy level was low but proposed own level as the medium. The differences between self-assessment and actual scores were significant for both female and male participants (Table 5, the difference at a high level $22 \%$ for both, and at low level $16 \%$ and $18 \%$, respectively).

In questions about confidence and interest the disparities among female and male students were minor (2 to $5 \%$ ). 
International Journal of Business and Applied Social Science (IJBASS)

\section{Table 5 Differences in self- assessments}

\begin{tabular}{|c|c|c|c|c|}
\hline \multirow{2}{*}{$\begin{array}{l}\text { A. Self-assessment about } \\
\text { financial knowledge? }\end{array}$} & \multicolumn{3}{|c|}{ Financial literacy level } & \multirow{2}{*}{$\begin{array}{c}\text { Full } \\
\text { sample }\end{array}$} \\
\hline & Low & Medium & High & \\
\hline High $\quad$ Count & 41 & 125 & 59 & 225 \\
\hline$\%$ within & $18.2 \%$ & $55.6 \%$ & $26.2 \%$ & $100.0 \%$ \\
\hline$\%$ within column & $29.5 \%$ & $42.8 \%$ & $56.2 \%$ & $42.0 \%$ \\
\hline Medium $\quad$ Count & 55 & 121 & 35 & 211 \\
\hline$\%$ within & $26.1 \%$ & $57.3 \%$ & $16.6 \%$ & $100.0 \%$ \\
\hline$\%$ within column & $39.6 \%$ & $41.4 \%$ & $33.3 \%$ & $39.4 \%$ \\
\hline $\begin{array}{ll}\text { Low } & \text { Count } \\
\end{array}$ & 23 & 20 & 2 & 45 \\
\hline$\%$ within & $51.1 \%$ & $44.4 \%$ & $4.4 \%$ & $100.0 \%$ \\
\hline$\%$ within column & $16.5 \%$ & $6.9 \%$ & $1.9 \%$ & $8.4 \%$ \\
\hline Hard to say Count & 20 & 26 & 9 & 55 \\
\hline$\%$ within & $36.4 \%$ & $47.3 \%$ & $16.3 \%$ & $100.0 \%$ \\
\hline$\%$ within column & $14.4 \%$ & $8.9 \%$ & $8.6 \%$ & $10.2 \%$ \\
\hline Total $\quad$ Count & 139 & 292 & 105 & 536 \\
\hline$\%$ of Total & $25.9 \%$ & $54.5 \%$ & $19.6 \%$ & $100.0 \%$ \\
\hline Note: & \multicolumn{4}{|c|}{$\begin{array}{c}\text { Chi-Square }=12.847 * \\
\text { Sig }=0.046\end{array}$} \\
\hline B. Self-assessment about & \multicolumn{3}{|c|}{ Financial literacy level } & Females \\
\hline financial knowledge? & Low & Medium & High & sample \\
\hline $\begin{array}{cc}\text { High } & \text { Count } \\
\end{array}$ & 17 & 49 & 31 & 97 \\
\hline$\%$ within & $17.5 \%$ & $50.5 \%$ & $32.0 \%$ & $100.0 \%$ \\
\hline$\%$ within column & $34.0 \%$ & $44.5 \%$ & $62.0 \%$ & $46.2 \%$ \\
\hline Medium $\quad$ Count & 17 & 41 & 16 & 74 \\
\hline$\%$ within & $23.0 \%$ & $55.4 \%$ & $21.6 \%$ & $100.0 \%$ \\
\hline$\%$ within column & $34.0 \%$ & $37.3 \%$ & $32.0 \%$ & $35.2 \%$ \\
\hline $\begin{array}{ll}\text { Low } & \text { Count } \\
\end{array}$ & 9 & 6 & 1 & 16 \\
\hline$\%$ within & $56.3 \%$ & $37.5 \%$ & $6.3 \%$ & $100.0 \%$ \\
\hline$\%$ within column & $18.0 \%$ & $5.5 \%$ & $2.0 \%$ & $7.6 \%$ \\
\hline Hard to say Count & 7 & 14 & 2 & 23 \\
\hline$\%$ within & $30.4 \%$ & $60.9 \%$ & $8.7 \%$ & $100.0 \%$ \\
\hline$\%$ within column & $14.0 \%$ & $12.7 \%$ & $4.0 \%$ & $11.0 \%$ \\
\hline Total $\quad$ Count & 50 & 110 & 50 & 210 \\
\hline$\%$ of Total & $23.8 \%$ & $52.4 \%$ & $23.8 \%$ & $100.0 \%$ \\
\hline Note: & \multicolumn{4}{|c|}{$\begin{array}{c}\text { Chi-Square }=17.446^{* *} \\
\text { Sig }=0.008\end{array}$} \\
\hline C. Self-assessment about & \multicolumn{3}{|c|}{ Financial literacy level } & Males \\
\hline financial knowledge? & Low & Medium & High & sample \\
\hline High $\quad$ Count & 24 & 76 & 28 & 128 \\
\hline$\%$ within & $18.8 \%$ & $59.4 \%$ & $21.9 \%$ & $100.0 \%$ \\
\hline$\%$ within column & $27.0 \%$ & $41.8 \%$ & $50.9 \%$ & $39.3 \%$ \\
\hline Medium $\quad$ Count & 38 & 80 & 19 & 137 \\
\hline$\%$ within & $27.7 \%$ & $54.4 \%$ & $13.9 \%$ & $100.0 \%$ \\
\hline$\%$ within column & $42.7 \%$ & $44.0 \%$ & $34.5 \%$ & $42,0 \%$ \\
\hline Low $\quad$ Count & 14 & 14 & 1 & 29 \\
\hline$\%$ within & $48.3 \%$ & $48.3 \%$ & $3.4 \%$ & $100.0 \%$ \\
\hline$\%$ within column & $15.7 \%$ & $7.7 \%$ & $1.8 \%$ & $8.9 \%$ \\
\hline Hard to say Count & 13 & 12 & 7 & 32 \\
\hline$\%$ within & $40.6 \%$ & $37.5 \%$ & $21.9 \%$ & $100.0 \%$ \\
\hline$\%$ within column & $14.6 \%$ & $6.6 \%$ & $12.7 \%$ & $9.8 \%$ \\
\hline Total $\quad$ Count & 89 & 182 & 55 & 326 \\
\hline$\%$ of Total & $27.3 \%$ & $55.8 \%$ & $16.9 \%$ & $100.0 \%$ \\
\hline Note: & \multicolumn{4}{|c|}{$\begin{array}{c}\text { Chi-Square }=19.067 * * \\
\text { Sig }=0.004\end{array}$} \\
\hline
\end{tabular}

Notes: $\mathrm{Sig}=$ significant at the level; $*$ significant at the 0.05 level; **significant at the 0.01 level or greater.

3.5 Students Sources of Personal Financial is of little importance and 5 is especially important. Position Education 6 has used in cases "Cannot say" or "Unanswered". 51\% of

Students asked to evaluate the importance of the women and $47 \%$ of men evaluated the knowledge financial knowledge they have acquired from different obtained from their parents especially important ("5"), financial education providers on a scale of 1 to 5 , where 1 and $27 \%$ of women and $24 \%$ of men important ("4"), (Figures 2B and 2C). 
Evaluation of the importance of the financial knowledge acquired from parents, family:
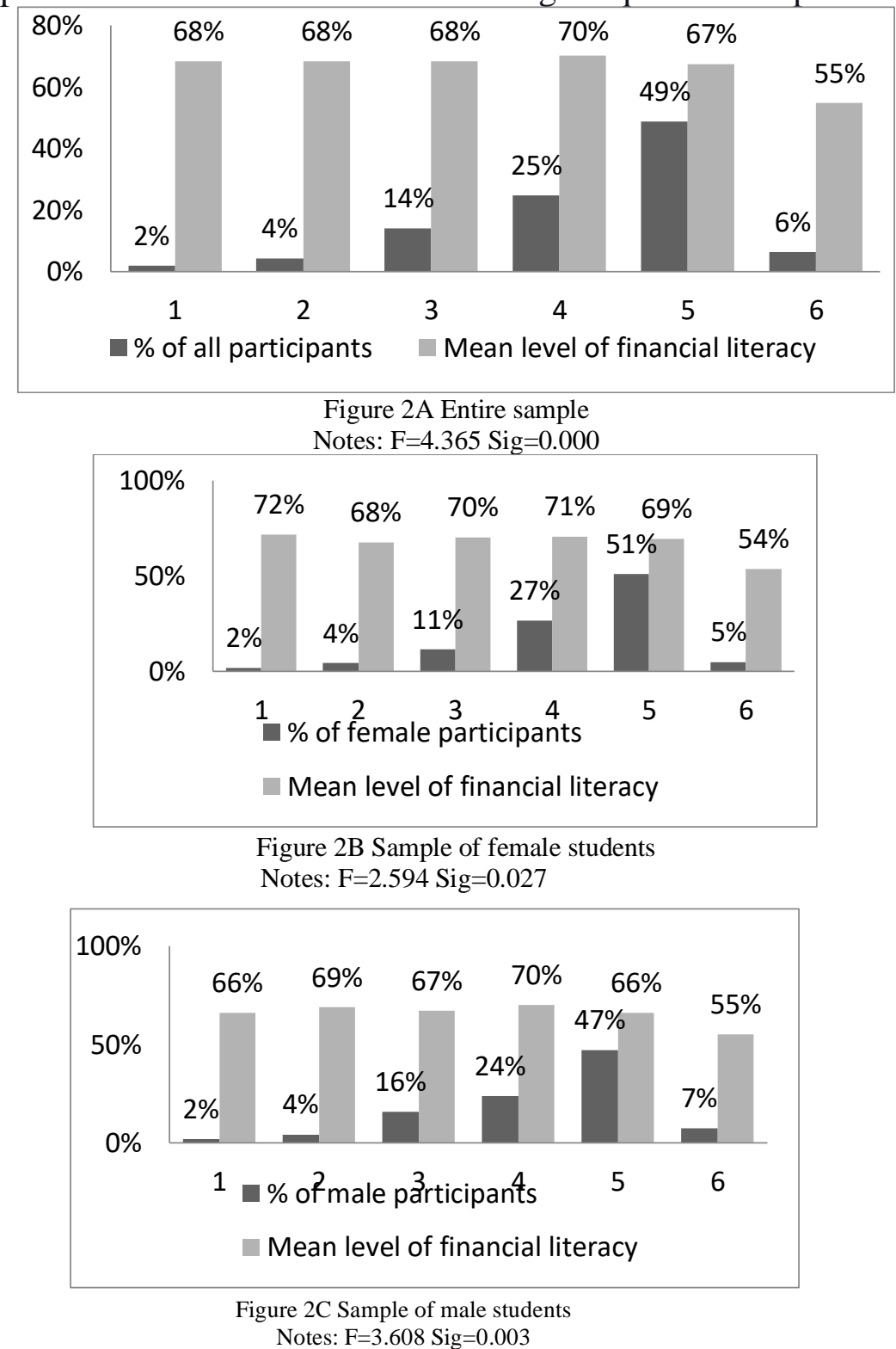

The next most important financial knowledge provider was university as it was evaluated by $49 \%$ of women and 52\% of men with grade "5" or "4" (Figures 3B and 3C).

Evaluation of the importance of the financial knowledge acquired from University

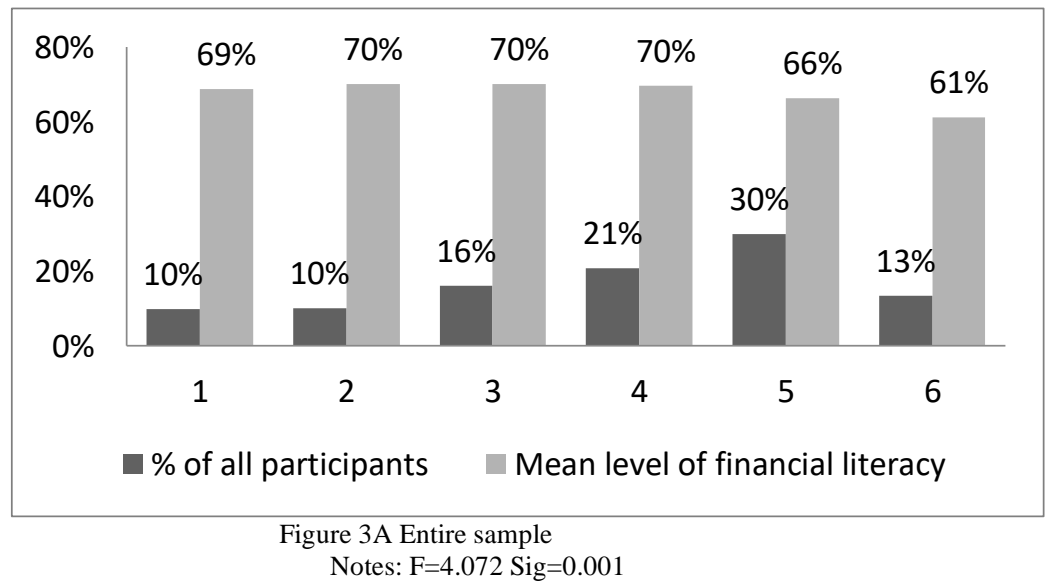



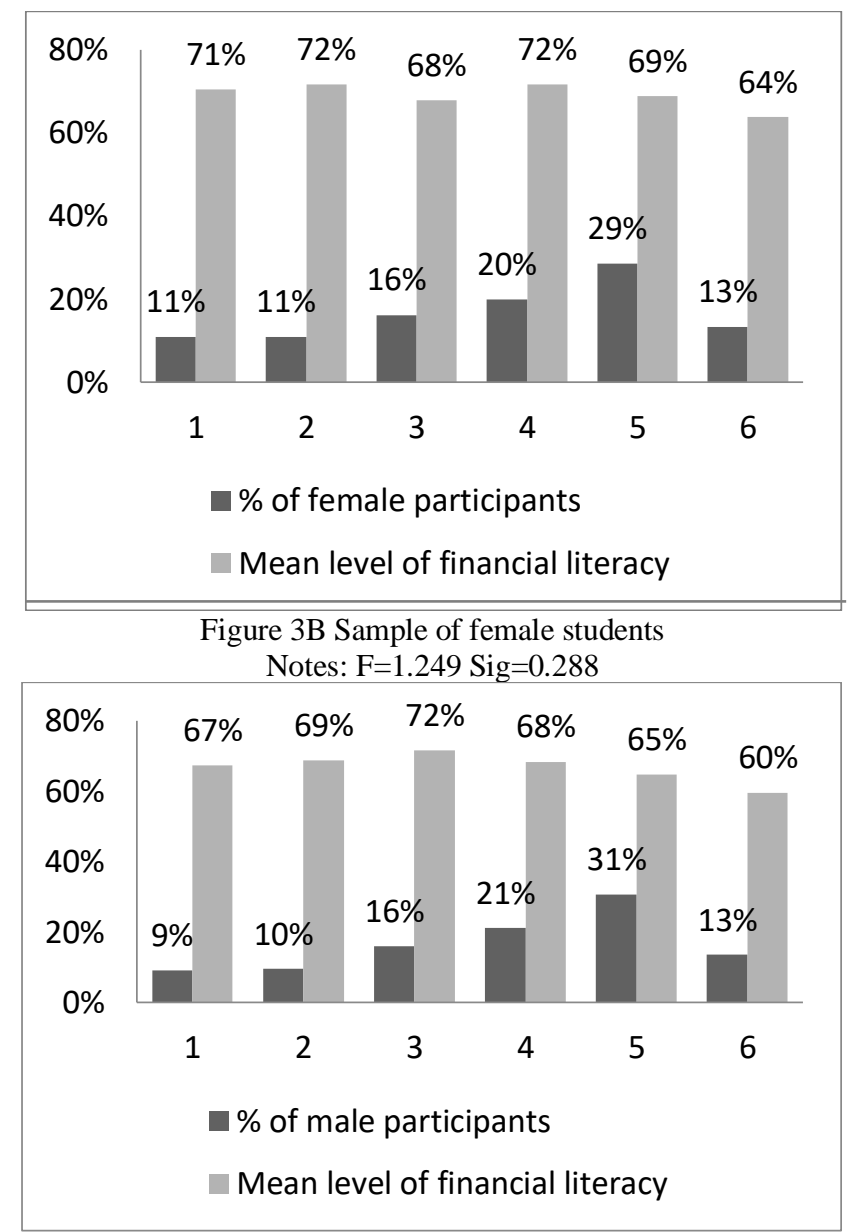

Figure 3C Sample of male students Notes: $\mathrm{F}=3.645 \mathrm{Sig}=0.003$

The personal financial knowledge acquired from High School had rated important, as 49\% of women and $50 \%$ of men evaluated it with grades "5" or "4" (Figures 4B and 4C).

Evaluation of the importance of the financial knowledge acquired from High School

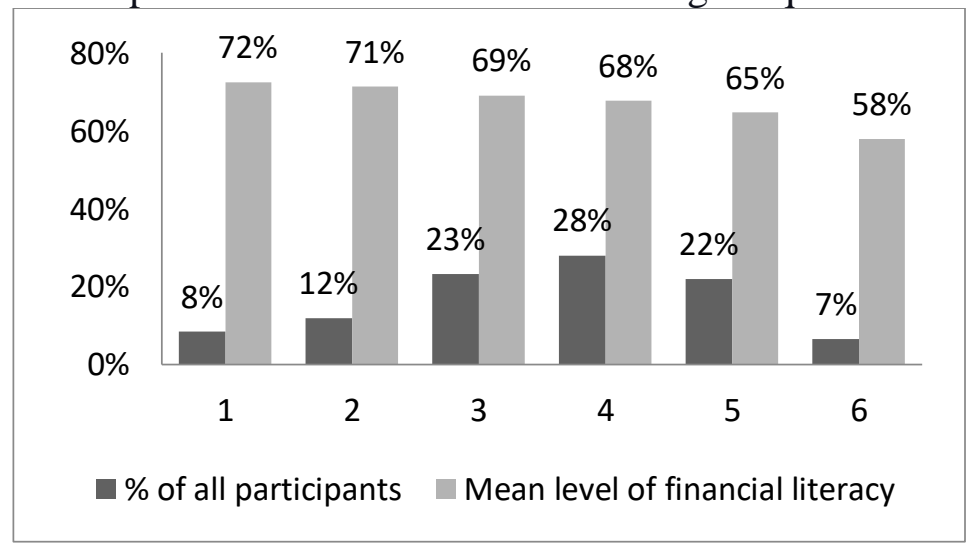

Figure 4A Entire sample

Notes: $\mathrm{F}=6.005 \mathrm{Sig}=0.000$ 


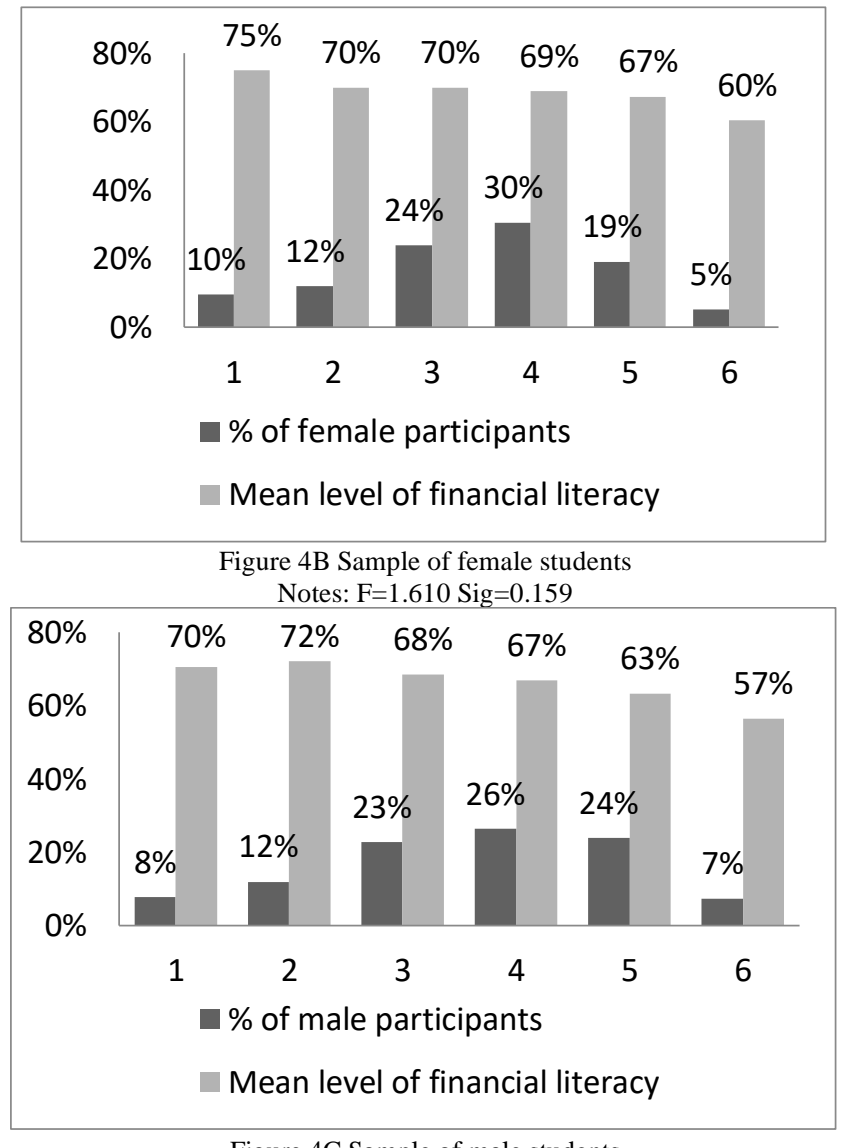

Figure 4C Sample of male students Notes: $\mathrm{F}=4.524 \mathrm{Sig}=0.001$

The importance of the financial knowledge that had acquired from Primary School had rated as little importance. The grade " 1 " had given by $62 \%$ of females and by $58 \%$ of male participants (Figures $5 \mathrm{~B}$ and $5 \mathrm{C}$ ).

Evaluation of the importance of the financial knowledge acquired from Primary School

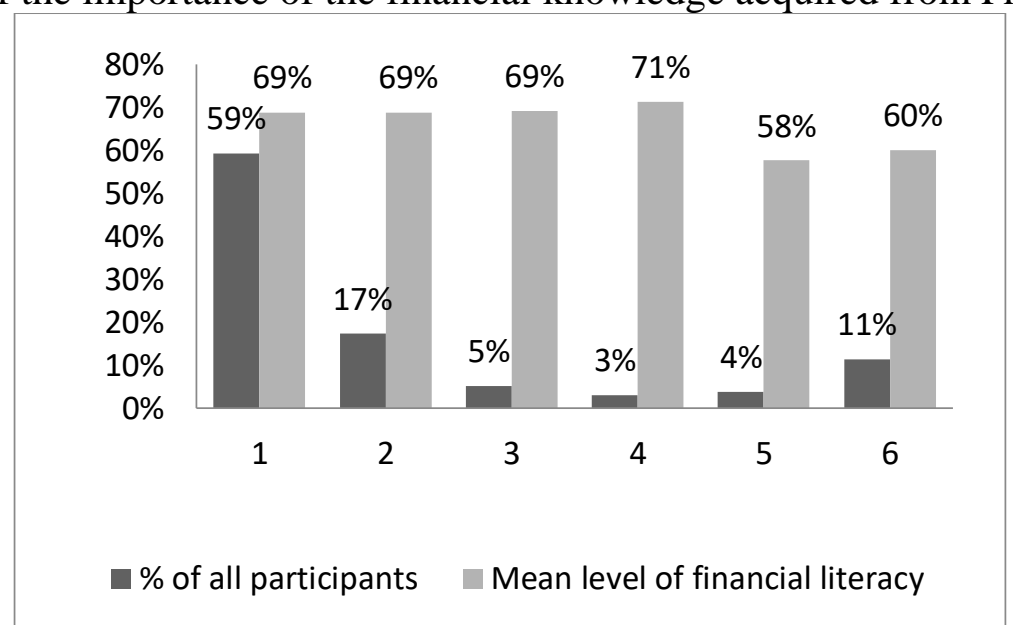




\section{International Journal of Business and Applied Social Science (IJBASS)}

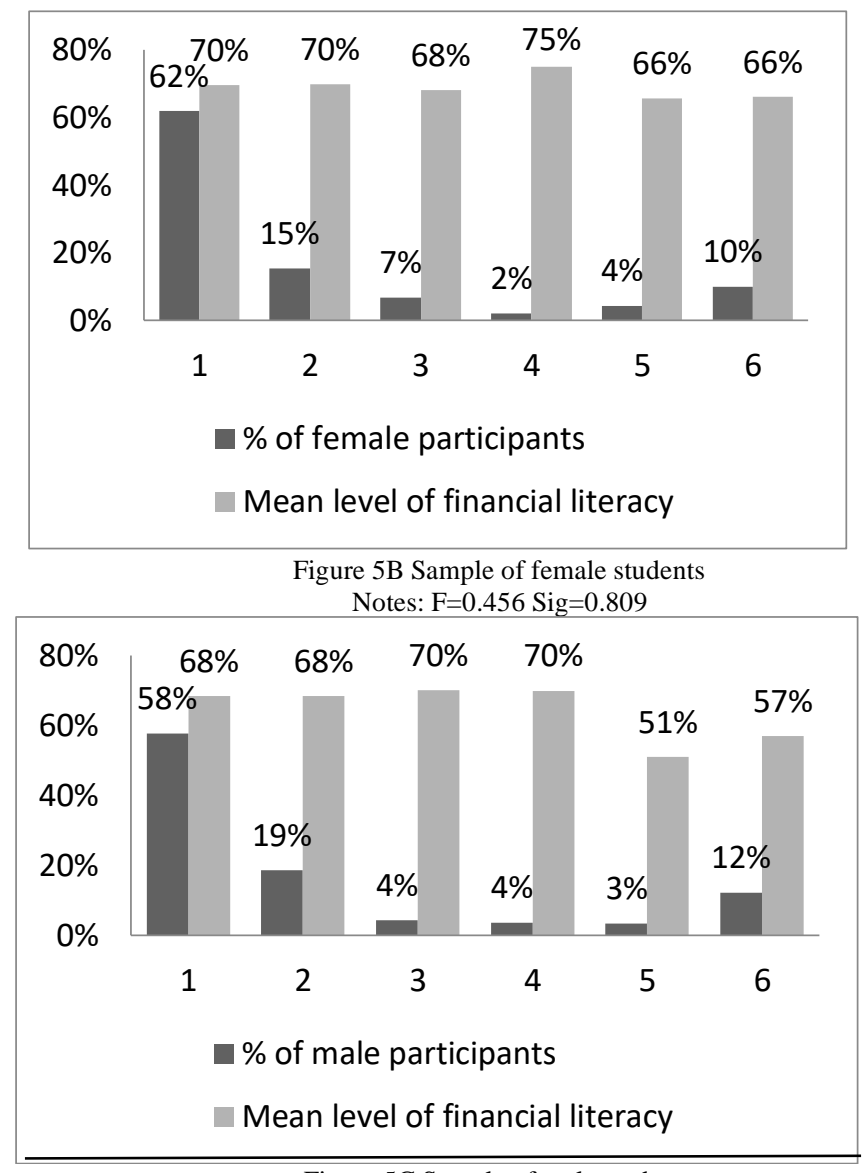

Figure 5C Sample of male students

Notes: $\mathrm{F}=6.820 \mathrm{Sig}=0.000$

F-statistic showed that there were no statistically significant differences between men's and women's results.

\section{Discussion}

Statistically significant results showed that on average female students know more $(69.1 \%)$ about personal finance than males $(66.5 \%)$. The previous study among Estonian university students (Mändmaa 2019b) revealed that men have a higher level of financial literacy than women and similar results got Atkinson et al. (2006) in interviewing UK population; Goldsmith \& Goldsmith $(1997 ; 2006)$ and Chen \& Volpe $(1998 ; 2002)$ while researching the US students; Lusardi et al. (2010) who examined the US youth and Monticone (2010) who studied the population of Italy. Wagland and Taylor (2009) who examined the level of financial literacy of Australian students, came to the result that gender does not affect the level of financial literacy. Altintas (2011), whose study was conducted in Turkey, and Pires and Quelhas (2015), whose study was conducted in Portugal, got similar results to the present study, that the level of female students' financial literacy is higher than males.

The important factors that affect the level of background academic discipline and level of education;

Experience the participants' age groups and the work experience; Demographic characteristics nationality and household size and income (Table 3 ). There were some differences between the samples of females and males, as factors like age, work experience, nationality, and income were not statistically significant for females and household size for males. Previous study results suggested that statistically significant factors that influencing Estonian university students' financial literacy were the academic discipline, level of education, gender, age, and nationality (Mändmaa 2019a).

Based on the current research it can be argued that the higher scores in financial literacy of female students have a direct relation to the choice of academic discipline, as female students from Civil Engineering department got the higher financial literacy scores than male students or students studying in any other study field (Table 3 ). The results, obtained by this survey, reflect the positive impact of mathematics and other number-oriented 
In the results of Pisa 2012, where girls and boys aged 15 were tested in financial literacy, there were no significant gender differences. The differences occurred when the results of the math and reading tests were included in the analysis, and students' whit similar scores were compared. Then the results showed that boys had a higher level of financial literacy than girls. Looking more closely at the results of the PISA test of Estonian students' in mathematics, it can be seen that since 2009 there is a statistically significant difference between the levels of girls and boys, with the average score of girls being lower (points in 2009: boys 516 and girls 508; points in 2012: boys 523 and girls 518). (SA Innove 2013) The gender gap in the results of the study conducted in 2012 among Estonian university students was statistically significant and the level of financial literacy of females was lower than that of males (females $56 \%$ and males $64 \%$ ). Students who studied on non-economic disciplines or other nonmath-oriented specialties got weaker results, and the share of correct responses in women was $53 \%$ and in men 63\%. (Mändmaa 2019a; Mändmaa 2019b)

The results of the girls' math tests and the female students' financial literacy assessments are supporting evidence of the relationship between mathematics skills and financial literacy levels.

Current study results confirm that students who use financial services have more knowledge in financial literacy (Table 4). The findings of a study conducted among Portuguese students showed that the existence of a prior experience, as credit clients or the existence of saving habits increases the financial literacy of individuals (Pires and Quelhas 2015). An earlier study conducted among Estonian university students exhibited that financial services with statistically significant effects were: Debit Card, Bank loan, Investment Services, and Insurance (Mändmaa 2019b). Present study results show that there are more financial services with statistically significant effect: Current Account; Debit Card; Credit Card, Housing loan; Insurance; Investment Services; Pension fund shares, but statistically significant gender differences have not revealed in this area (Table 4).

Previous research has found that people with low financial literacy have more likely problems with debt and less likely to participate in the stock market (Lusardi and Tufano 2009; van Rooij et al. 2007). The results of this study show that students' use of loan instruments was low, but investments were not popular either, and there were no statistically significant differences between female and male students in the use of the financial services (Table 5). As an explanation of the current situation, it should mention the relatively short period of post-socialism, during which the habits of the population have not yet changed, and the Estonians conservative attitude towards money matters.

In the USA conducted a survey among undergraduate students, $84 \%$ of participants said they needed more education on financial management topics (Sallie Mae, 2009). In a previous study in Estonia to the question "Do you want to get more information about financial services and monetary affairs planning?" $65 \%$ of the participants answered "yes". More curiosity had students with low financial literacy levels (below the median $57.14 \%$ level). The level of interest to get additional information about financial services and monetary affairs planning among male and female students was quite similar. Male students' interest was just 5\% lower. (Mändmaa, 2019b)

In the present survey the students' opinions, about needs to improve their financial literacy, showed the rising trend, as $79 \%$ of female students and $84 \%$ of male (Figure 1) students reported that they have the interest to improve their financial literacy. The level of male students' interest was 5\% higher, while the level of financial literacy was higher among female students (accordingly females' $69 \%$ and males' $66 \%$ ).

To evaluate students' confidence, they were asked to assess their own financial literacy level. The level was assessed rightly by 203 students, which accounted for $38 \%$ of respondents in the full sample (Table 5), including $39 \%$ of females and $37 \%$ of male students. Students who assessed their financial knowledge to the high level (225 incl. 97 female and 128 male students) could be counted self-confident, as well as those (55 incl. 17 female students and 38 male students) whose financial literacy level was low but proposed own level as the medium.

Previous studies (Goldsmith and Goldsmith 1997; Chen and Volpe 2002) observed that women have lower confidence in and less interest to personal finance than men do and pointed to those as possible reasons for gender differences in financial literacy. The results of the current study do not confirm these observations, as nearly half $(46 \%)$ of female participants rated their financial knowledge to a High level, and that shows rather higher than low confidence. At the same time, the disparities between female and male students were minor, in selfassessments and in having an interest in topics of personal finances. 
To evaluate the sources of personal financial study showed that female students' financial literacy knowledge, students were asked to rate the importance of results may be higher than male students' if the selected the acquired financial education and knowledge academic discipline is linked with mathematics. So, it providers. The highly rated source of personal financial could be stated that the existence of an interest in education for female and male students was family, the University and High School were the next (Figures 2, 3 and 4). Primary School (Figure 5) was marked of little importance for $56 \%$ of students (female $62 \%$ and male $58 \%)$.

The discussion can be concluded by agreeing with earlier researchers' opinions that further development of financial education in university is important, as students have expressed interest and the results of the students' financial literacy assessment show the need for improvement. In addition, students will be soon the founders of the family themselves, and the parents' financial knowledge and ability to manage resources efficiently are important factors in the development of the next generation's financial well-being.

\section{Conclusion}

This study analyzed the responses collected from Estonian university students by the survey questionnaire, in order to evaluate students' financial literacy in purpose to develop personal financial education. 536 students, 210 women, and 326 men participated in the survey and by the results their financial literacy level was Medium. The study showed statistically significant gender differences in financial literacy. On average, female students answered correctly to $69.1 \%$ of questions, while male students had the correct answers of $66.5 \%$. Lower scores mainly concerned topics of insurance and interest formation. The important factors that affected the level of financial literacy of women and men were: Participants' Education academic discipline and level of education; Experience participants age group and work experience; Demographic characteristics - nationality and household size; Income; and the use of Financial services (Current Account, Debit Card, Credit Card, Home Loan, Insurance, Investment Services, Pension Funds Shares). $82 \%$ of all participants ( $84 \%$ of males and $79 \%$ of females) admitted their interest to improve the financial literacy level. The highly-rated source of personal finance education for female and male students was family, and the university was the next.

Several previous studies have shown that men have a higher level of financial literacy than women and a few studies have referred to the low interest of female students about financial topics and mathematics or other number-oriented subjects as reasons. The results of this mathematics, as a numerical and logical subject, supports the orientation in financial systems and helps to improve one's personal as well more broadly social financial wellbeing.

Unfortunately, this study could not give the full answers about what boosts the math interest, not either why are there gender differences in financial literacy or how to manage them. There are myths and gender roles having their effects. The myths that girls are weaker in mathematics or science could hinder their advancement, as these may occur some aversion to the subject. To reverse the situation the education system is in a privileged position as several studies show that students are successful in the subjects they like.

Students' financial literacy, choices, and opinions were assessed for the purpose to find the need and gaps in students' knowledge to develop personal financial education. The survey gave a great overview but for better outcomes, the study should be continued as there are still a lot of open questions.

This study found out that the form of a questionnaire is good for evaluation but not particularly enough for improvement in the courses.

The current study had its limits, as the questionnaire was anonymous, there was no ability to contact participants later. For better outcomes there should be added the question about participant's contact data - phone number or e-mail address, to clarify their views and let them express their perspectives on, for example about the inclusion of the necessary topics, explanations, etc.

Nowadays financial literacy is essential as in a society much of the financial responsibility has shifted from governments to the individual. Further development of financial education in universities is important, as students' financial literacy assessment shows the need for improvement, and students will be our next financially active generation leaders, family founders, parents, etc. This study provides sound evidence for researchers and will be useful for politicians and educators in the purpose to develop financial education.

\section{Acknowledgment}

The author would like to thank colleagues and students from Tallinn University of Technology for their valuable help in data gathering. 


\section{CCenter for Promoting Education and Research (CPER) USA}

WWW.cpernet.org

\section{References}

Altintas, K. M. (2011). "The dynamics of financial literacy within the framework of personal finance: An analysis among Turkish University Students." African Journal of Business Management 5(26): 10483 10491. http://www.academicjournals.org/app/webroot/article/article1380526343_Altintas.pdf

Atkinson, A., S. McKay, E. Kempson and S. Collard. (2006). "Levels of Financial Capability in the UK: Results of a baseline survey." University of Bristol: Personal Finance Research Centre. 150 pp. http://www.pfrc.bris.ac.uk/publications/Reports/Fincap_baseline_results_06.pdf

Chen, H. and R. P. Volpe. (1998). "An Analysis of Personal Financial Literacy among College Students." Financial Services Review, 7(2): 107-128.

https://doi.org/10.1016/S1057-0810(99)80006-7

Chen, H. and R. P. Volpe. (2002). "Gender Differences in Personal Financial Literacy among College Students." Financial Services Review, 11(3): 289-307

https://www.researchgate.net/publication/285358406_Gender_Differences_in_Personal_Financial_Literacy_Among _College_Students

Cole, S. A., A. L. Paulson and G. K. Shastry. (2012). "Smart Money: The Effect of Education on Financial Behaviour.” Harvard Business School Finance Working Paper No. 09-071. http://dx.doi.org/10.2139/ssrn.1317298

Goldsmith, E. B. and R. E. Goldsmith. (1997). "Gender differences in perceived and real knowledge of financial investments." Psychological Report, 80: 236-238. https://doi.org/10.2466/pr0.1997.80.1.236

Goldsmith, E. B. and R. E. Goldsmith. (2006). "The Effects of Investment Education on Gender Differences in Financial Knowledge.” Journal of Personal Finance. 5(2): 55-69.

https://www.academia.edu/2833951/The_effects_of_investment_education_on_gender_differences_in_financial_kno wledge

Lusardi, A. and O. S. Mitchell. (2006). "Financial Literacy and Planning: Implications for Retirement Wellbeing.” Working Paper, Pension Research Council, Wharton School, University of Pennsylvania. https://pensionresearchcouncil.wharton.upenn.edu/wp-content/uploads/2015/09/PRC-WP-2006-1.pdf

Lusardi, A. and P. Tufano. (2009). "Debt Literacy, Financial Experiences, and Over indebtedness." NBER Working Paper, 14808. https://doi.org/10.3386/w14808

Lusardi, A., O. S. Mitchell and V. Curto. (2010). "Financial Literacy among the Young". Journal of Consumer Affairs 44: 358-380. https://doi.org/10.1111/j.1745-6606.2010.01173.x

Lusardi, A. (2017). Visiting Swedish House of Finance to share her research and receive Skandia's 2017 research award. https://www.houseoffinance.se/lusardi-financial-literacy-levels-need-robust-intervention/

Mandell, L. (2008). "The Financial Literacy of Young American Adults. Results of the 2008 National JumpStart Coalition Survey of High School Seniors and College Students." JumpStart Coalition: 1253. https://www.stockmarketgame.org/assets/pdf/2008\%20JumpStart\%20Financial\%20Literacy\%20Survey.pdf

Monticone, C. (2010). "How Much Does Wealth Matter in the Acquisition of Financial Literacy?" Journal of Consumer Affairs 44 (2): 403 - 422. https://doi.org/10.1111/j.1745-6606.2010.01175.x

Mändmaa, S. (2019a). "Financial literacy - what and why should we improve." Eurasian Journal of Social Sciences, 7(2), 2019, 12-28. https://doi.org/10.15604/ejss.2019.07.02.002

Mändmaa, S. (2019b). "Analysing the factors influencing university students' financial literacy." International Journal for Innovation Education and Research, 7(7): 465-497.

https://doi.org/10.31686/ijier.Vol7.Iss7.1628

OECD 2006. "Improving Financial Literacy: Analysis of Issues and Policies." Financial Market Trends 2005/2. https://dx.doi.org/10.1787/fmt-v2005-art11-en 
OECD 2012. "Measuring Financial Literacy: Results of the OECD / International Network on Financial Education (INFE) Pilot Study," OECD Working Papers on Finance, Insurance and Private Pensions No. 15. https://dx.doi.org/10.1787/5k9csfs90fr4-en

OECD 2014. PISA 2012 "Results: Students and Money: Financial Literacy Skills for the 21st Century." PISA, OECD Publishing Volume VI. http://dx.doi.org/10.1787/9789264208094-en

Pires, V. and A. P. Quelhas. (2015). "Financial Literacy among the Higher Education Students: Empirical Evidence for the Portuguese Case." Portuguese Journal of Finance, Management and Accounting. 1 (1): $84-$ 103. http://u3isjournal.isvouga.pt/index.php/PJFMA

Remund, D. L. (2010). "Financial Literacy Explicated: The Case for a Clearer Definition in an Increasingly Complex Economy." Journal of Consumer Affairs, 44 (2): 276-295. https://onlinelibrary.wiley.com/doi/epdf/10.1111/j.1745-6606.2010.01169.x

van Rooij, M., A. Lusardi and R. Alessie. (2007). "Financial Literacy and Stock Market Participation." NBER Working Paper 13565. https://www.nber.org/papers/w13565.pdf

SA Innove. (2013). "Results of PISA 2012 Estonia." [PISA 2012 Eesti tulemused]. edited by Gunda Tire, Tallinn Dec 4, 2013, SA Innove. https://issuu.com/innove/docs/pisa_2012_eesti_tulemused_2

Sallie Mae. (2009). "How Undergraduate Students Use Credit Cards.” [Online] Sallie Mae's National Study of Usage Rates and Trends 2009. http://static.mgnetwork.com/rtd/pdfs/20090830_iris.pdf

Wagland, S. P., Taylor, S. (2009). "When it comes to financial literacy, is gender really an issue? "Australasian Accounting Business \& Finance Journal 3(1): 13 - 25.

https://ro.uow.edu.au/cgi/viewcontent.cgi?referer=https://www.bing.com/\&httpsredir=1\&article=1049\&context=aab fj 